\title{
Correction
}

\section{Correction: A Complete Set of Nascent Transcription Rates for Yeast Genes}

\section{The PLOS ONE Staff}

There is an error in Supporting Information Table S3. The headings in columns $\mathrm{G}$ and $\mathrm{H}$ are interchanged. Please view the corrected table below.

\section{Supporting Information}

Table S3. Percentage of TR devoted to compensate the dilution effect due to the cell growth. The TR necessary to compensate the dilution is computed using the RA and a generation time of 113 minutes. As the TR necessary to compensate the dilution is computed independently to the nascent TR some values show percentage greater than $100 \%$ or are negative. In those cases we have arbitrary substituted the values to either $100 \%$ or $0 \%$, meaning that the TR devoted to compensate the dilution is much larger $(100 \%)$ or negligible $(0 \%)$ in respect to the TR devoted to compensate the degradation.

(XLS)

\section{Reference}

1. Pelechano V, Chávez S, Pérez-Ortín JE (2010) A Complete Set of Nascent Transcription Rates for Yeast Genes. PLoS ONE 5(11): e15442. doi:10.1371/ journal.pone.0015442
Citation: The PLOS ONE Staff (2014) Correction: A Complete Set of Nascent Transcription Rates for Yeast Genes. PLoS ONE 9(12): e115560. doi:10.1371/ journal.pone. 0115560

Published December 5, 2014

Copyright: () 2014 The PLOS ONE Staff. This is an open-access article distributed under the terms of the Creative Commons Attribution License, which permits unrestricted use, distribution, and reproduction in any medium, provided the original author and source are credited. 